\title{
An Assessment of the Impact of Road Construction on Land Use Pattern in Urban Centres in Nigeria, A Case Study of Jalingo LGA, Taraba State Nigeria
}

\author{
E. D. Oruonye \\ Department of Geography, Taraba State University, P.M.B. 1167, Jalingo, Taraba State, Nigeria \\ Email: emmyodan@yahoo.uk, eoruonye@gmail.com
}

Doi:10.5901/mjss.2014.v5n10p82

\begin{abstract}
The rapid growth of Jalingo metropolis in Taraba State Nigeria has necessitated the development of transportation facilities to accommodate relative increases in population and vehicle traffic. This study examines the impact of road construction on land use patterns, land value changes and the economic, social and environmental impacts that result. Questionnaires were used to collect data for the study and were analyzed using simple descriptive statistics, particularly frequencies, percentages and ratios. Analysis of variance was used to assess variation in land values over time along the newly constructed roads in the Metropolis. Physical inspection of the study area was undertaken to obtain first hand information on various uses along the major roads newly constructed in the study area. The findings of this study shows that land use along the major newly constructed roads has undergone a substantial level of change from agricultural farm lands and open fields to residential and commercial uses with the later becoming more prevalent. Alongside this change is a corresponding increase in both rental and capital values of landed properties on both sides of the newly constructed roads in the study area. Influx of people and traders into Jalingo metropolis because of its relative peace contributed to these actions and afterwards, the advantage of complimentarity provided by the road becomes the factor attracting more residential and business activities into the area. The study noted that with the expansion of Jalingo metropolis through the expansion of the urban road network, there is need to put adequate development control mechanism in place for maximum effectiveness. The town planning authority should enforce the implementation of the provisions of the Jalingo urban master plan to allow for balance in land allocation for various uses.
\end{abstract}

Keywords: Assessment, Construction, Land use, Land value, Pattern, Urban and Impact.

\section{Introduction}

Road transport network development has significant total impact on land use patterns (Moore and Throsnes, 1994; Kelly, 1994). Transportation and land use are inexorably connected. Everything that happens to land use has transportation implications and every transportation action affects land use. Land use and transportation are mutually interconnected (Mitchell and Rapkin, 1952).

Transportation's most significant impact on land development occurs when access is provided to land. Increased access to land raises its potential for development, and more development generates additional travel. Once access has been provided, land patterns begin to change over a period of time. The results of these changes are, for the most part, irreversible.

The use of the term "land use" is based on the fact that through development, urban space accommodates a great variety of human activities. Land is a convenient measure of space, and land use provides a spatial accounting framework for urban development and activities (Oduwaye et al, 2011). The location of activities and their need for interaction creates the demand for transportation, while the provision of transport facilities influences the location itself. Land uses, by virtue of their occupancy, are taken to generate interaction needs (trip generation), and these needs are directed to specific targets by specific transportation facilities (trip distribution and modal split). According to Oduwaye et al (2011), several works have been done on the relationship between land use and transportation most of which are concentrated in developed countries of the world. The degree of this relationship has been studied by many scholars such as Kuzmyak and Pratt (2003), TRL (2004), Bento et al, (2003) and Turcotte (2008). Asuquo (1981) observed that land use and transportation are mutually embedded and that the organization of land use activities in any city basically rests on the effective linkages of the transport network system. Adeniji (1993) observed that throughout the history of human settlements, transportation has always been closely related to the structure and density of settlement and the use of land and that transport route generates different land uses on its sides. The conflict between them obviously stems from the physical structure of towns as a result of structural conversion of buildings (Banjo 1984).

Automobile transportation tends to significantly increase the amount of land devoted to transportation facilities (Litman, 2006). Increase in the amount of land devoted to transportation facilities means less land available for other 
productive uses within that area. Increase in population growth has seen urban boundaries shifted to cover what was once peri-urban and agricultural land. The rapid growth of Jalingo metropolis has necessitated the development of transportation facilities to accommodate relative increases in population and vehicle traffic. This study therefore examines the impact of road construction on land use patterns, land value changes and the economic, social and environmental impacts that result from the expansion of transport network.

\section{Study Area}

Jalingo LGA is roughly located between latitudes $8^{\circ} 47^{\prime}$ to $9^{\circ} 01^{\prime} \mathrm{N}$ and longitudes $11^{\circ} 09^{\prime}$ to $11^{\circ} 30^{\prime} \mathrm{E}$. It is bounded to the North by Lau Local Government Area, to the East by Yorro Local Government Area, to the South and West by Ardo Kola Local Government Area. Jalingo town was founded in 1893, as a convenient and suitable site for the relocation of the administrative centre of the Muri emirate. By extension the name Jalingo, pronounced as Ja-li-ngo simply means the victorious, following the nature of the struggle that gave birth to the establishment of the town. The present day Jalingo Local Government Council was an offshoot of the abolished native authority system. It has a total land area of about $195 \mathrm{~km}^{2}$. Jalingo LGA has a population of 139,845 people according to the 2006 population census, with a projected growth rate of 3\% (Shawulu et al, 2009). Presently, it has a projected population of 165,774 based on the 2006 population census figure of 139,845 at $3.1 \%$ annual growth rate.

Presently, Jalingo town is experiencing increasing population and shortage of infrastructural facilities, including road connectivity. The urban road network construction was embarked upon by the present government to improve connectivity in road network within the town and to facilitate movement of people and flow of commodities within the metropolis (Oruonye, 2011). The road construction is also meant to help in the expansion of the metropolis so as to accommodate the increasing urban population and need for more social amenities.

As an emerging urban complex, Jalingo has developed a more or less linear settlement pattern dictated by the nature of its topography. Rivers Lamurde and Mayo Goi together almost limited the growth of the town on the southern part for a long time. The construction of new roads and bridges along major rivers that bordered the town on the southeast and southwest have in recent times opened up large areas for urban growth. The second and third bridges along Mayo Goi River at Pantinapu and Nyabu Kaka and the new bridge across Lamurde river at Karofi are among recent developments that are encouraging and stimulating urban growth. Hitherto, lands across these Mayo Goi and Lamurde rivers remained undervalued and generally reserved for agricultural use only.

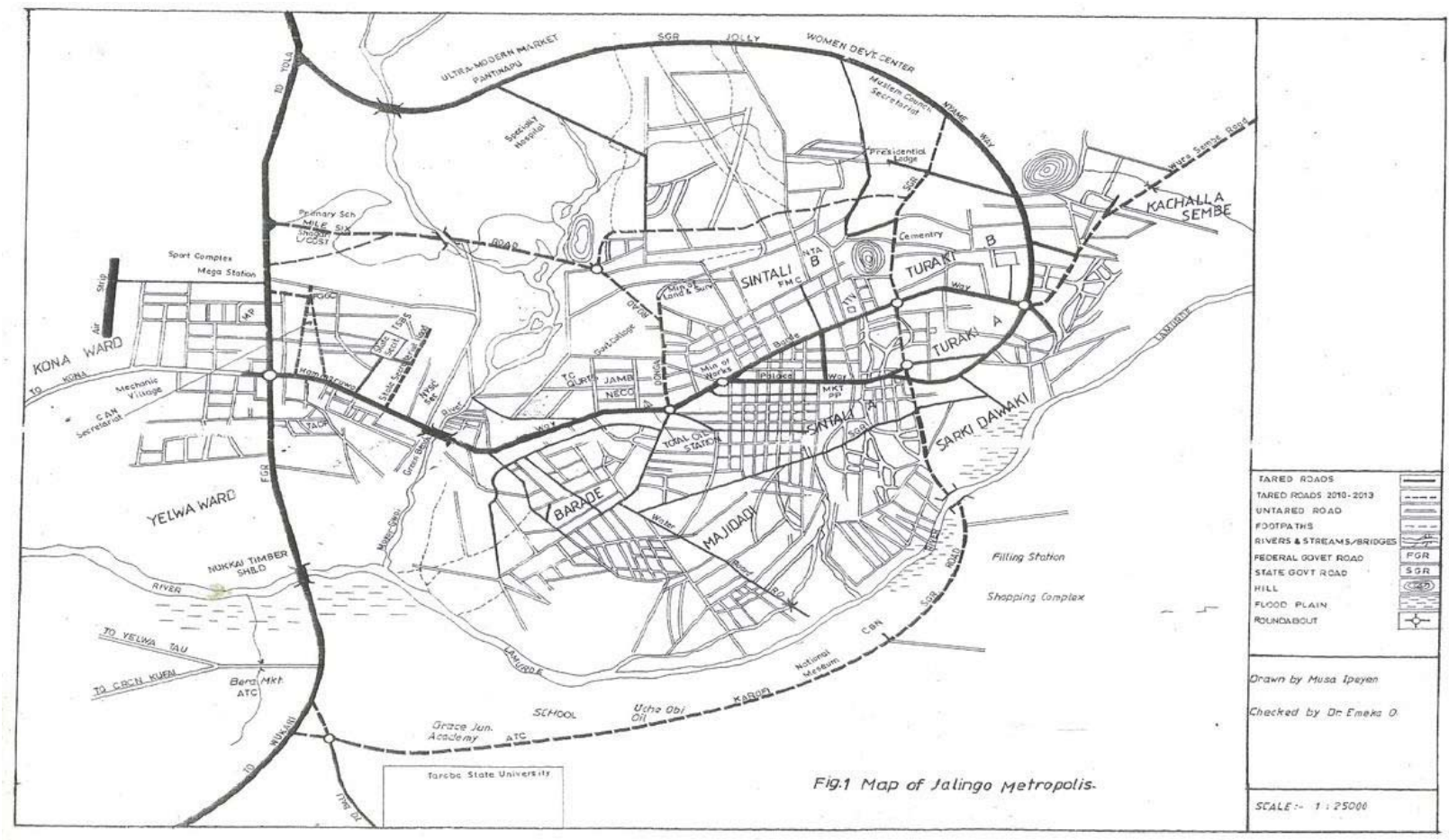




\section{Material and Methods}

Land use changes as common phenomenon in urban areas is becoming very much noticeable along the major new roads constructed by the Taraba state government in Jalingo metropolis. Jalingo metropolis is therefore chosen as a focus of this study because of the high level of changes here in the past 20 years. In carrying out this study, we adopted a descriptive analysis approach and survey design method to examine the changes in real estate value along the vicinity of the bypass and other newly constructed roads in the town. The specific variables to be analyzed in this paper are the changes in land property values over time and changes in land use including the spatial distribution of residential housing and business activities of various types. A questionnaire was drawn and randomly distributed to residents along the major newly constructed roads. In all, 65 questionnaires were administered in the study area. The questionnaires were analyzed using the analysis of variance technique and simple descriptive statistics, particularly frequencies and percentages. Physical inspection of the study area was undertaken to obtain first hand information on various uses, property values and rental cost along the major roads newly constructed in the study area.

\section{Results}

\subsection{Land use Changes in the study area}

The findings of the study show that the existing land use in the urban periphery (outskirt) of Jalingo Metropolis was predominantly agricultural farmlands. Movement to these lands was hitherto limited by the River Lamurde that traversed the area and lack of access roads. Following the construction of the bye-pass road and Karofi bridge on the river and other road network extension, people begin to move into these areas, resulting into the conversion of prime agricultural lands into commercial and residential uses. This is also the case with the Mile six and Nassarawa road axis. The continuous infiltration of residential and commercial uses over the past two decades is gradually changing the face of the area. The road construction was necessitated by the increasing population of Jalingo metropolis from about 68,000 inhabitants in 1991 to about 160,000 people today (2013 projection). Thus, the new road construction facilitated the outward expansion of the town and resulted in changes in land use whereby the residents buy up prime agricultural land for commercial and residential purposes. New residential houses are fast springing up all over the areas along with shopping stores and filling stations. The desire for residential accommodation had thus led to the proliferation of housing especially in terms of its quality and distribution resulting to various levels of development violations in some places. It is a common sight to see land use conversions which does not allow for access road.

Some of the commercial land uses that have developed in the study area were found on both side of the newly constructed road. These land uses include the new Central Bank of Nigeria office Complex, the new Jalingo modern market complex, a number of filling stations and institutions such as the Nigeria Police residential complex, the Yagai Academy, the Taraba State School of Nursing and Midfery among others. The predominant commercial uses include: office buildings of various types, shopping complexes of various sizes and types. The Institutional land uses include educational land and building-primary, secondary and tertiary institutions, Police stations/barracks. Other land uses include petrol filling/service stations and open market places. Almost all the respondents interviewed (100\%) agreed that there have been drastic changes in land use in the last decade following the construction of the new roads in the study area as shown in Table 1.

Table 1. Changes in Land uses in the Study area

\begin{tabular}{|c|l|c|c|}
\hline S/NO & Land use changes in the study area & No. of Respondents & Percentage (\%) \\
\hline 1 & Agricultural - Residential & 27 & 41.5 \\
\hline 2 & Agricultural - Commercial & 15 & 23.1 \\
\hline 3 & Commercial - Residential & 02 & 3.1 \\
\hline 4 & Agricultural - Institutional & 12 & 18.5 \\
\hline 5 & Residential - Commercial & 9 & 13.8 \\
\hline 6 & Total & 65 & 100 \\
\hline
\end{tabular}

Source: Fieldwork, 2013 


\subsection{Factors Influencing land use changes in the study area}

The factors that have influenced the land use changes include accessibility provided by the new road, location of the place, recent development in the surrounding, topography and quite nature of the area, economic activities in the neighbourhood, cost of land, individual preferences, life style choices, other infrastructure, local planning policies among others. The result of the finding shows that the variables that determine land use in the area include closeness to the new road, accessibility and level of development in the surroundings (number of houses around the neighbourhood) (Table 2). Thus, land close to newly built houses are fast developed and cost more than land in areas that are far away from existing buildings and major roads. Land that have no access roads are usually left as open spaces or fallow land, and in some cases are still cultivated. These land usually have low value because it is assume that it will take time (many years) before development could get there. On the other hand, the land that are along the newly constructed road are in high demand and command high value because of their proximity to the major road. Most of them are used for building commercial shopping stores and complex, petroleum filling station, office complex, educational institutions among others.

Table 2. Influencing Factors of Land use Changes in the Study area

\begin{tabular}{|c|l|c|c|}
\hline S/NO & \multicolumn{1}{|c|}{ Factors influencing Land use } & No. of Respondents & Percentage (\%) \\
\hline 1 & Closeness to new road & 16 & 24.6 \\
\hline 2 & Level of development in the area & 13 & 20 \\
\hline 3 & Topography & 5 & 7.6 \\
\hline 4 & Cost of land & 11 & 16.9 \\
\hline 5 & Accessibility of plot & 12 & 18.5 \\
\hline 6 & Others (Please specify) & 8 & 12.4 \\
\hline 7 & Total & 65 & 100 \\
\hline
\end{tabular}

Source: Fieldwork, 2013.

\subsection{Change in Land and Property value}

The study findings show significant changes in the values of landed properties over the last two decades. These changes were further enhanced by the construction of the new road networks in the area. The study findings show that there were no buildings in most places in the study area about 20 years ago. For example, about $65 \%$ of the people remarked that there were no three bedrooms flat in their area two decades ago, and a decade ago, the average cost of three bedroom was about N140,000 and presently it cost about N250,000. The analysis of variance result shows that these changes in the rental cost of a 3 bedroom flat is significant $p<.05$ (Table 3).

Table 3. ANOVA results of changes in rental cost of 3 bedroom flat over time in the study area

\begin{tabular}{|c|c|c|c|c|c|}
\multicolumn{1}{c|}{ ANOVA } & & & & \\
\cline { 2 - 6 } & & & & $\mathrm{F}$ & Sig. \\
\hline Between Groups & $3.705 \mathrm{E} 11$ & 2 & $1.852 \mathrm{E} 11$ & 111.913 & .000 \\
Within Groups & $3.178 \mathrm{E} 11$ & 192 & $1.655 \mathrm{E} 9$ & & \\
Total & $6.883 \mathrm{E} 11$ & 194 & & & \\
\hline
\end{tabular}

Also about $55 \%$ of the respondents affirmed that there were no single room rental in their area two decades ago, while $30 \%$ insist that one single room in their area was usually lease out free to visitors without collecting any rentals. $15 \%$ of the respondents said that a single room was usually rented out at N200 per annum two decades ago, N5,000 per annum a decade ago and presently between N10,000 per annum for mud houses and N25,000 per annum for brick wall houses (Table 4). 
Table 4. Changes in Land and Property values over the last two decades

\begin{tabular}{|c|c|c|c|c|}
\hline Years & $\begin{array}{c}\text { Average Cost of a Plot of } \\
\text { Land }(100 \times 50 \mathrm{~m})(\mathrm{Nair})\end{array}$ & $\begin{array}{c}\text { Average Rental Value of three } \\
\text { Flat Bedroom (Naira) }\end{array}$ & $\begin{array}{c}\text { Average Rental Value of a } \\
\text { Single room (Naira) }\end{array}$ & $\begin{array}{c}\text { Average Rental Value of } \\
\text { a single shop (Naira) }\end{array}$ \\
\hline 20 years ago & 10,000 & $\mathrm{~N} 8,000$ (where available) & 500 & $\mathrm{~N} 10$ \\
\hline 10 years ago & 37,000 & 140,000 & 5,000 & $\mathrm{~N} 200$ \\
\hline Presently & 360,000 & 250,000 & $\begin{array}{c}10,000 \text { (mud house) to } \\
24,000 \text { (brick house) }\end{array}$ & $\mathrm{N} 50,000$ \\
\hline
\end{tabular}

The analysis of variance result shows a significant difference in the rental cost of a single room over the years in the study area (Table 5). Also 45\% of the respondents insist that there were no shops in their area two decades ago, 15\% insist it was free, while in some area, the cost of a single shop is about N10 per annum two decades ago (Table 4). This gradually rose to N200 per annum a decade ago and recently to about N30,000 and in some places N50,000 per annum presently as shown in Table 4 . The analysis of variance result shows a significant difference $p<.05$ in the changes in rental cost of a single shop over time.

Table 5. ANOVA of changes in rental cost of a single shop over time in the study area

\begin{tabular}{|c|c|c|c|c|c|}
\multicolumn{1}{c|}{ ANOVA } \\
\cline { 2 - 7 } \multicolumn{1}{c|}{ COST } & Sum of Squares & df & Mean Square & F & Sig. \\
\hline & $4.420 \mathrm{E} 10$ & 2 & $2.210 \mathrm{E} 10$ & 37.217 & .000 \\
\hline Between Groups & $1.140 \mathrm{E} 11$ & 192 & $5.938 \mathrm{E} 8$ & & \\
Within Groups & $1.582 \mathrm{E} 11$ & 194 & & & \\
Total & & & & & \\
\hline
\end{tabular}

Table 6. ANOVA of changes in rental cost of a single room over time in the study area

\begin{tabular}{|c|c|c|c|c|c|}
\multicolumn{1}{c|}{ ANOVA } \\
\cline { 2 - 6 } \multicolumn{1}{c|}{ COST } & Sum of Squares & df & Mean Square & F & Sig. \\
\hline & $1.523 \mathrm{E} 10$ & 2 & $7.614 \mathrm{E} 9$ & 92.784 & .000 \\
\hline Between Groups & $1.576 \mathrm{E} 10$ & 192 & $8.206 \mathrm{E} 7$ & & \\
Within Groups & $3.098 \mathrm{E} 10$ & 194 & & & \\
Total & & & & & \\
\hline
\end{tabular}

The study findings show that in the past people do not have measuring instruments or scale to split a portion of land for sale. They normally make reference to some landmark features to show the size of their plot that they want to sale. Sometimes, the use their walking strides to measure the plot. With time a plot of land was considered to measure $100 \mathrm{x}$ $50 \mathrm{~m}$. This single plot of land $(100 \mathrm{~m} \times 50 \mathrm{~m})$ cost N10,000 on the average two decades ago, N37,000 a decade ago and recently following the road construction and the general rush for landed properties in the study area, the cost of a plot now is about N360,000 (about 100\% increase). The analysis of variance result shows a significant difference $p<.05$ in the changes in the cost of landed property in the area (Table 7).

Table 7. ANOVA of land value changes over time in the study area

\begin{tabular}{|c|c|c|c|c|c|}
\multicolumn{1}{c|}{ ANOVA } \\
\cline { 2 - 7 } \multicolumn{1}{c|}{} & & & & & \\
\hline & Sum of Squares & df & Mean Square & F & Sig. \\
\hline Between Groups & 5.250 E12 & 2 & $2.625 E 12$ & 162.094 & .000 \\
Within Groups & $3.109 E 12$ & 192 & 1.620 E10 & & \\
Total & 8.360 E12 & 194 & & & \\
\hline
\end{tabular}




\subsection{Effect of Landuse changes on property values}

The effect of the land use changes on the property values can be appreciated from Table 4 which shows how the rental and capital values of both residential and commercial properties appreciated in the last two decades. Some of the observed effects of the changes in land use in the study area include increased economic activities and demand for landed properties as shown in Table 8.

Table 8. Observed Effects of Changes in Landuse in the Study area

\begin{tabular}{|c|l|c|c|}
\hline S/NO & Land use changes in the study area & No. of Respondents & Percentage (\%) \\
\hline 1 & Traffic congestion & 4 & 6.2 \\
\hline 2 & Increased economic activities & 18 & 27.7 \\
\hline 3 & Increased demand for land & 23 & 35.4 \\
\hline 4 & Noise pollution & 3 & 4.6 \\
\hline 5 & Over-stretched facilities & 2 & 3.1 \\
\hline 6 & No effect observed & 15 & 23 \\
\hline 7 & Others (Please specify) & 0 & 0 \\
\hline 8 & Total & 65 & 100 \\
\hline
\end{tabular}

The study revealed that the factors of demand and supply are the major determinants of land use in study area. About $35.4 \%$ of the surveyed population attested to this. Increase in demand for residential and commercial properties has led to conversion of prime agricultural lands (which was the predominant landuse in the area) to residential and commercial uses. An increasing change of land use has occurred in the study area in the last ten years on both side of the newly constructed road. Amongst the major changes is the conversion of agricultural lands from farmlands to residential and commercial uses. The result of the study also shows a high trend of property values over the last decade. Due to increase in population and demand for residential accommodation, economic activities in the area soared and this led to increase in demand for residential and commercial properties.

\subsection{Effectiveness of town planning regulations}

The finding of the study shows that the Town Planning department of the Bureau of Land and Surveying enforces town planning regulations in the study area. The findings also show that there are existing regulations guiding the development of structures and buildings in any part of the town. Potential property developers are expected to apply to the town planning department attaching the building plan and design. The town planning department will then undertake a site survey of the area to ensure that the proposed building conforms to the Master Plan of the town before granting permission. However, most of the respondents $63 \%$ interviewed believe that the laws governing land use in the area are effective and are being enforced by the relevant authority while $37 \%$ believed that the enforcement of such regulations are ineffective considering the sporadic changes that take place within this decade and some of the glaring violations in some places.

Urban land use is the physical manifestation of socio-economic, cultural, political and environmental forces shaping the use of land in urban areas (Akinmoladun and Oduwaye, 2000). The spatial pattern and nature of proportion of land uses in urban area is largely influenced by the national policies and economy such as housing policy, transportation, agricultural policy and development of communication technologies (Adebayo, 2009). Generally, urban land is used for various purposes but the most common types of uses include residential, commercial, industrial, recreational, transportation, public and semi-public uses. The proportion of the area covered by different land uses are influenced by many factors which include socio-economic, physical and environmental, technical infrastructure, government policies and laws (Adebayo, 2009). In Jalingo metropolis, some areas are exclusively planned for residential uses; these areas include the GRAs, Commissioner's quarters, Mile six housing estate, Shagari and Magami lowcost housing estates. The commercial areas include areas used for activities such as market places, shops, shopping complexes, offices and exhibition centres. Although some of these specific uses are planned for in the Metropolis, others grew out of the spontaneous needs of the community in a residential area. The construction of access roads - both pedestrian and vehicular usually lead to upspring of blocks of offices and shopping complexes along the access routes, thereby resulting in changes in land use pattern and property values. Institutional land uses include areas prepared for the major institutions of government at all levels (federal, state and local). These include schools, hospitals, police stations, post 
office, cemeteries, place of worship and barracks.

\section{Conclusion and Recommendation}

The findings of this study shows that land use along the major newly constructed roads has undergone a substantial level of change from agricultural farm lands and open fields to residential and commercial uses with the later becoming more prevalent. Alongside this change is a corresponding increase in both rental and capital values of landed properties on both sides of the newly constructed roads in the study area. Influx of people and traders into Jalingo metropolis because of its relative peace contributed to these actions and afterwards, the advantage of complimentarity provided by the new road becomes the factor attracting more business activities into the area. The increase in demand for residential and commercial use in turn leads to increase in property values. This change in land use leading to higher property values has its positive impact on the metropolis. This include reduction in traffic congestion at the city centre, relief to the over stretched infrastructural facilities at the city centre and increase in open spaces and relaxation/recreation centres. With the expansion of Jalingo metropolis through the expansion of the urban road network, there is need to put adequate development control mechanism in place for maximum effectiveness and compliance to laid down regulations. The town planning authority should enforce the implementation of the provisions of the Jalingo urban master plan to allow for balance in land allocation for various uses.

\section{References}

Adebayo, M.A. (2009). Impact of Urban Land use changes on Property Values in Metropolitan Lagos. The Social Sciences, Vol. 4, No. 1, pp. 111-117.

Adeniji, K. (1993) Transport Subsidies in Nigeria, NISER, Ibadan.

Akinmoladun, I.O. and L. Oduwaye (2000). Democratizing the Planning Process in Nigeria through Public Participation: A Challenge to Town Planners in the Twenty-First Century. Journal of the Nigerian Institute of Town Planners, XIII (2): 1-11 (2000).

Asuquo, B. O. (1981) "System Approach: Evaluating Land use and Transport Coupling", in Ekanem and Onakomaiya (eds.)Transportation in Nigerian National Development, Proceedings of a National Conference, NISER, Ibadan, pp. 31 - 44.

Banjo, G. A. (1984) "Towards a New Framework for Transport Planning in Third World

Cities". Proceedings of "Invited Papers" at 13th Meeting of Australian Road Research Board. Bento, A. M., Cropper, M. L., Mobarak, A. M. and Vinha K. (2003), The Impact of Urban Spatial Structure on Travel Demand in the United States, World Bank Group Working Paper 2007, World Bank http://papers.ssrn.com/sol3/papers.cfm?abstract_id=636369); published in The Review of Economics and Statistics (http://mitpress.mit.edu), Vol. 87, Issue 3 - August 2005, pp. 466 - 478.

Litman T (2006), Transportation Cost and Benefit Analysis: Techniques, Estimates and Implications, Victoria Transport Policy Institute (www.vtpi.org/tca).

Kelly, E.D. (1994) 'The transportation land-use link', Journal of Planning Literature, November, Vol. 9, No. 2, pp.128-145.

Kuzmyak, R. J. and Pratt, R. H. (2003), Land Use and Site Design: Traveler Response to Transport System Changes, Chapter 15, Report 95, Transit Cooperative Research Program; Transportation Research Board (www.trb.org).

Mitchell, Robert B., and Chester Rapkin, 1954, Urban Traffic: a Function of Land Use,Columbia University Press, New York.

Moore T. and Thorsnes P. (1994), The Transportation/Land Use Connection, Planning Advisory Service Report 448/449, American Planning Association (www. planning.org).

Oduwaye L, Alade W and Adekunke S. (2011) Land Use and Traffic Pattern along Lagos-Badagry Corridor, Lagos, Nigeria. Proceedings REAL CORP 2011 Tagungsband. 18-20 May 2011. Pp. 525 - 532. http://www.corp.at

Ogba C. and Okon I (2012) Assessment of the Impact of land use characteristics on residential choice making: implication to urban transit planning in Port Harcourt, Nigeria. FIG Working Week 2012. Knowing to manage the territory, protect the environment, evaluate the cultural heritage Rome, Italy 6-10 May 2012.

Oruonye, E.D. and Abbas Bashir (2011). The Geography of Taraba State, Nigeria. LAP Publishing Company, Germany.

Oruonye, E.D. (2011) An Assessment of the Socio-Economic Impact of Urban Development-Induced Resettlement Scheme in Nigerian Cities: A Case Study of the Nyamusala - ATC Road Construction in Jalingo Metropolis, Taraba State. International Review of Social Sciences and Humanities (IRSSH) Vol. 3 (1) pp. 1-9. www.irssh.com

Shawulu, H.M., Adebayo, A.A. and Binbol, N.L. (2008). "Appraisal of the National Poverty Eradication Programme (NAPEP) in Jalingo Local Government Area, Taraba State Nigeria". Medwell Journals. The Social Sciences 3(4):291-296.

TRL (2004), The Demand for Public Transit: A Practical Guide, Transportation Research Laboratory, Report TRL 593 (www.trl.co.uk). This 240-page document is a detailed analysis of factors that affect transit demand, including demographic and geographic factors.

Turcotte, M. (2008), "Dependence on Cars in Urban Neighbourhoods: Life in Metropolitan Areas," Canadian Social Trends, Statistics Canada (www.statcan.ca); at www.statcan.ca/english/freepub/11-008-XIE/2008001/article/10503-en.htm. 